infants at swimming pools and parents of infants who wilfully refuse to isolate, by a safety barrier, a water hazard in the home may be considered neglectful. We think that the psychodynamics here, however, are quite different from those where the parent makes a conscious act of aggression using the full bathtub as the agent.

It would be fruitful to investigate retrospectively hospital admissions for pneumonia and acute respiratory symptoms of children who are known to have been abused in other ways. It is important to include non-accidental injury in the differential diagnosis of atypical childhood bathtub immersions; all children presenting as such should be identified in the appropriate "at-risk" register in the admission room or casualty department.

${ }^{1}$ Rodgers, D, et al, British Medical fournal, 1976, 1, 793.

2 Pearn, J, et al, Medical fournal of Australia, in press.

${ }^{3}$ Gil, D G, Violence against Children: Physical Child Abuse in the United States, Cambridge, Mass, Harvard University Press, 1970.

4 Caffey, J, Pediatrics, 1974, 54, 396.

${ }^{5}$ Birrell, R G, and Birrell, J H W, Medical fournal of Australia, 1968, 2, 1023.

(Accepted 13 October 1976)

Department of Child Health, Royal Children's Hospital, Brisbane, Australia 4029

JAMES NIXON, BSOCWK, senior tutor in medical social work

JOHN PEARN, MD, MRCP, reader in child health

\section{Rhabdomyolysis and acute tubular necrosis associated with carbenoxolone and diuretic treatment}

Carbenoxolone sodium has been used for several years for treating gastric ulcers. Several side effects have been reported, including salt and water retention, hypertension, and potassium depletion. ${ }^{1}$ We report here another complication: acute tubular necrosis.

\section{Case report}

A gastric ulcer was diagnosed in this 61-year-old man who had been admitted on 11 November 1975 for haematemesis. His blood pressure was $160 / 100 \mathrm{~mm} \mathrm{Hg}$. Measurement of serum electrolytes and renal function and urine analysis showed no abnormalities. Carbenoxolone $300 \mathrm{mg} / \mathrm{day}$ was prescribed.

Early in December chlorthalidone $50 \mathrm{mg}$ every other day was added to control ankle oedema. Carbenoxolone was continued at the same dose. No potassium supplement was given. At the end of December the patient complained of progressive muscle weakness, mental confusion, and disorientation. Drug treatment was continued.

The patient was readmitted on 8 January 1976 for rapidly progressive oliguria. He had an ataxic gait and profound muscle weakness of the four limbs. Deep tendon reflexes were diminished. There was no other neurological abnormality. Blood pressure was $160 / 90 \mathrm{~mm} \mathrm{Hg}$. The results of laboratory investigations are shown in the table. Definite hypokalaemic alkalosis was associated with severe renal failure. Serum transaminase and creatinine phosphokinase concentrations were strikingly high. $200 \mathrm{ml}$ of dark brown urine was obtained by bladder catheterisation. Despite the absence of red and white blood cells in the sediment, the orthotolidine test was positive. Urinary sodium $(27 \mathrm{mmol}(\mathrm{mEq}) / \mathrm{l})$ and urea $(1287 \mathrm{mmol}(7.75 \mathrm{~g}) / \mathrm{l})$ levels were compatible with acute tubular necrosis.

The electrocardiogram was typical of hypokalaemia with multiple ventricular ectopics. Intravenous pyelography disclosed normal sized kidneys. An early, faint, stable nephrogram typical of acute tubular necrosis was obtained. Electromyography disclosed muscle fibre lesions and a mild decrease of motor nerve conduction velocity.

Muscle biopsy confirmed the existence of focal muscle necrosis. A renal biopsy performed 12 days after admission showed flattened tubular cells with numerous mitoses and mild interstitial oedema without cellular infiltrate-a picture suggestive of recovering acute tubular necrosis. No immunoglobulins, complement, or fibrinogen were detected. The patient retained $800 \mathrm{mmol}$ $(\mathrm{mEq})$ of potassium during the first five days. Muscular abnormalities subsided promptly. Anuria persisted for 10 days, so six haemodialyses were performed. Renal function returned subsequently towards normal and continued to improve after the patient's discharge on 7 February 1976 (see table).

\section{Comment}

Acute tubular necrosis is not an unexpected complication of carbenoxolone treatment. As a result of its aldosterone-like effect carbenoxolone may produce profound potassium depletion with severe muscle lesions and occasionally myoglobulinuria, ${ }^{2-4}$ an abnormality known to cause acute tubular necrosis. ${ }^{5}$ The diagnosis of acute tubular necrosis in our patient relied on the clinical picture and $x$-ray and renal biopsy findings. Besides myoglobinuria no other causal factor such as sepsis, shock, or intoxication was present. Although myoglobin was not directly measured in the urine, the association of a strongly positive orthotolidine test and the absence of red cells in the urine is very suggestive of its presence. ${ }^{5}$ Myoglobinuria reflected the extensive muscle necrosis indicated by both muscle biopsy and the raised levels of serum enzymes of muscular origin. Muscle damage probably resulted from potassium depletion. On admission potassium deficit was severe, as shown by hypokalaemia despite renal failure and the subsequent retention of $800 \mathrm{mmol}$ of potassium. It resulted from combined carbenoxolone and diuretic therapy. Carbenoxolone was given at high doses for too long (seven weeks). Furthermore, carbenoxolone's kaliuretic properties were greatly enhanced by the addition of a diuretic without potassium supplementation. ${ }^{1}$

This case not only illustrates a new complication of carbenoxolone but also provides a new example of acute tubular necrosis produced by non-traumatic rhabdomyolysis, a condition diagnosed with increasing frequency. ${ }^{5}$

Requests for reprints should be sent to Professor C van Ypersele.

1 Pinder, R M, et al, Drugs, 1976, 11, 245.

${ }^{2}$ Mohamed, S D, Chapman, R S, and Crooks, J, British Medical fournal, 1966, 1, 1581.

${ }^{3}$ Davies, G J, Rhodes, J, and Calcraft, B J, British Medical fournal, 1974, $3,400$.

${ }^{4}$ Royston, A, and Prout, B J, British Medical fournal, 1976, 2, 150.

${ }^{5}$ Grossman, R A, et al, New England fournal of Medicine, 1974, 291, 807.

(Accepted 14 October 1976)

Renal Unit, Department of Medicine, Cliniques Universitaires St Pierre, University of Louvain, Louvain, Belgium

C DESCAMPS, MD, resident

J M VANDENBROUCKE, MD, chef de clinique adjoint

C VAN YPERSELE DE STRIHOU, MD, professor of medicine

\begin{tabular}{|c|c|c|c|c|c|c|}
\hline & $\underset{(\mathrm{mmol} / \mathrm{l})}{\text { Urea }}$ & $\underset{(\mu \mathrm{mol} / \mathrm{l})}{\text { Creatinine }}$ & $\underset{(\mathrm{mmol} / \mathrm{l})}{\text { Potassium }}$ & $\underset{(\mathrm{mmol} / \mathrm{l})}{\text { Total } \mathrm{CO}_{2}}$ & $\begin{array}{l}\text { Creatinine* } \\
\text { phosphokinase } \\
\text { (IU/1) }\end{array}$ & $\begin{array}{l}\text { Serum aspartate } \\
\text { aminotransferase } \\
\text { (IU / })\end{array}$ \\
\hline $\begin{array}{l}8 \text { January } \\
10 \text { January } \\
4 \text { February } \\
3 \text { March } \\
19 \text { May }\end{array}$ & $\begin{array}{l}48 \cdot 1 \\
53 \cdot 1 \\
19 \cdot 6 \\
11 \cdot 0 \\
11 \cdot 6\end{array}$ & $\begin{array}{r}1193 \\
1370 \\
301 \\
177 \\
168\end{array}$ & $\begin{array}{l}1 \cdot 4 \\
2 \cdot 2 \\
3 \cdot 8 \\
4 \cdot 6 \\
4.9\end{array}$ & $\begin{array}{l}36 \\
40 \\
26 \\
25 \\
24\end{array}$ & $\begin{array}{r}4400 \\
26 \\
31 \\
35\end{array}$ & $\begin{array}{r}550 \\
400 \\
18 \\
12 \\
20\end{array}$ \\
\hline
\end{tabular}

*Normal range: 3-65 IU/1. †Normal range: 6-30 IU/1.

Conversion: SI to traditional units-Urea: $1 \mathrm{mmol} / 1 \approx 6 \mathrm{mg} / 100 \mathrm{ml}$. Creatinine: $1 \mu \mathrm{mol} / 1 \approx 0.0113 \mathrm{mg} / 100 \mathrm{ml} . \mathrm{Potassium}: 1 \mathrm{mmol} / \mathrm{l}=1 \mathrm{mEq} / \mathrm{l} . \mathrm{CO}{ }^{2}: 1 \mathrm{mmol} / 1=1 \mathrm{mEq} / 1$. 